\title{
Spatial and temporal trend in monthly and annual reference evapotranspiration in Madagascar for the 1980-2010 period
}

\begin{abstract}
The temporal trend and spatial distribution of reference evapotranspiration was investigated across Madagascar for the period of 1980-2010. Air temperature, relative humidity, solar radiation, and wind speed were collected from 22 weather stations across the country and were used to estimate daily reference evapotranspiration $\left(\mathrm{ET}_{0}\right)$ by the Penman-Monteith equation. Monthly average daily $\mathrm{ET}_{0}$ and the total annual $\mathrm{ET}_{0}$ were estimated. The MannKendall test was used for the temporal trend analysis in monthly average daily $\mathrm{ET}_{0}$ and the total annual $\mathrm{ET}_{0}$ and the Sen's method was used to estimate the rate of change in $\mathrm{ET}_{0}$ during the study period. The spline interpolation method was used for spatial interpolation of the variation in annual and monthly average $\mathrm{ET}_{0}$. The results showed southwest-north East trend in $\mathrm{ET}_{0}$. Reference evapotranspiration was higher at the western semiarid region than the humid eastern region. $\mathrm{ET}_{0}$ peaked during the period of September-October. Annual total $\mathrm{ET}_{0}$ varied from $1,081 \mathrm{~mm}$ in Andapa at northeast to 2,239 $\mathrm{mm}$ in Antsohihy at northwestern coastal region. Overall, there was an increasing trend in annual total $\mathrm{ET}_{0}$; however, the upward trend was significant only at 7 out of 22 weather station sites while monthly $\mathrm{ET}_{0}$ did not show consistent trends. This is one of the first comprehensive studies that investigate spatial and temporal dynamics of $\mathrm{ET}_{0}$ in Madagascar, which can aid in developing appropriate adaptation strategies to improve crop water use and evaporative losses estimates for maintaining or increasing food production while enhancing water use efficiency in the western semiarid regions of Madagascar.
\end{abstract}

Volume 2 Issue 2 - 2018

\author{
Koffi Djaman,' Papa Malick Ndiaye, ${ }^{2}$ Komlan \\ Koudahe, ${ }^{3}$ Ansoumana Bodian, ${ }^{2}$ Lamine \\ Diop, ${ }^{4}$ Michael O'Neill,' Suat Irmak ${ }^{5}$ \\ 'Department of Plant and Environmental Sciences, New Mexico \\ State University, Agricultural Science Center at Farmington, \\ USA \\ ${ }^{2}$ Leïdi Laboratory Dynamics of territories and development, \\ Gaston Berger University, Saint Louis, Senegal \\ ${ }^{3}$ ADA Consulting Africa, Togo \\ ${ }^{4}$ UFR S2ATA, Gaston Berger University, Saint Louis, Senegal \\ ${ }^{5}$ Department of Biological Systems Engineering, University of \\ Nebraska-Lincoln, USA
}

Correspondence: Koffi Djaman, Department of Plant and Environmental Sciences, New Mexico State University, New Mexico, USA, Email kdjaman@nmsu.edu

Received: November 20, 2017 | Published: March 0I, 2018

Keywords: Penman-Monteith, Reference evapotranspiration, Spatio-temporal trend, Madagascar

\section{Introduction}

Reference evapotranspiration $\left(\mathrm{ET}_{0}\right)$ is one the most important parameters in agricultural, hydrological, and environmental studies. Despite the availability of numerous estimation methods, the Penman Monteith reference evapotranspiration method is the most accurate and being adopted worldwide and is recommended as a standardized method for $\mathrm{ET}_{0}$ estimation under different climatic conditions. ${ }^{1-2}$ Hourly, daily, seasonal, and annual $\mathrm{ET}_{0}$ are used for water resources planning, irrigation scheduling, rainfed agriculture, and the wetlands management. Evapotranspiration constitutes the main source of water losses at field, watershed and basin level as it is defined as the sum of the water loss by evaporation from various surfaces and transpiration from plant leaves. With the rising air temperatures on a global scale, an increase in $\mathrm{ET}_{0}$ is expected as revealed by number of studies. Increasing trend in annual $\mathrm{ET}_{0}$ was reported at $70 \%$ of examined weather stations in Iran with slopes varying from 2.30 to $11.28 \mathrm{~mm} /$ year. ${ }^{3}$ Similar trend in $\mathrm{ET}_{0}$ was found in Serbia. ${ }^{4}$ Upward trend in $\mathrm{ET}_{0}$ was reported at the rate of $1.4 \mathrm{~mm}$ per year during the 1957-2008 period in the Southern Italy. ${ }^{5}$ Significant increase in annual $\mathrm{ET}_{0}$ was reported for the Southern Senegal for the period of 1950-2000 at the rate of 2.43,4.08,0.55 and $1.85 \mathrm{~mm} /$ year at Tambakounda, Kedougou, Kolda and Ziguinchor, respectively, ${ }^{6}$ In Southwest China, Feng et al. ${ }^{7}$ found a declining trend in annual $\mathrm{ET}_{0}$ at a rate of $0.15 \mathrm{~mm} /$ year during the 1954-2013 period. While $\mathrm{ET}_{0}$ is showing an increasing trend in some parts of the world, it has been reported to decline in other parts.
Song et al. ${ }^{8}$ reported significant decreasing trend in annual $\mathrm{ET}_{0}$ across the North China Plain at the rate of $1.19 \mathrm{~mm} / \mathrm{year}$ for the period of 1961-2006. Similarly, annual and seasonal $\mathrm{ET}_{0}$ showed significant decreasing trend in North-East India. ${ }^{9}$ Irmak et al ${ }^{10}$ reported decrease in $\mathrm{ET}_{0}$ with a rate of $0.3596 \mathrm{~mm} / \mathrm{year}$ for the period of 1893 to 2008 in the Platte River Basin, central Nebraska-USA and they attributed this decrease to an increase in precipitation with a rate of about $0.90 \mathrm{~mm} /$ year that significantly reduces the available energy. Huo et al. ${ }^{11}$ also found a decreasing trend in annual $\mathrm{ET}_{0}$ at the rate of $3 \mathrm{~mm} / \mathrm{year}$ in the North West China for the period of 1955-2008 due to the increase in precipitation as reported by Irmak et al. ${ }^{10}$ Zhang et al. ${ }^{12}$ reported that annual $\mathrm{ET}_{0}$ significantly declined at the rate of $1.29 \mathrm{~mm} / \mathrm{year}$ from 1961 to 2012 in the Yellow River Basin, China. Xu et al. ${ }^{13}$ reported a significant decreasing trend in $\mathrm{ET}_{0}$ mainly caused by a significant decrease in the net radiation and a significant decrease in wind speed in Changjiang (Yangtze River) watershed. Liu \& Zhang ${ }^{14}$ indicated that in the driest Northwest region of China, $\mathrm{ET}_{0}$ decreased from 1960 to 1993 at the rate of $2.34 \mathrm{~mm} /$ year and increased thereafter up to 2010 at the rate of $4.80 \mathrm{~mm} /$ year. Xing et al. ${ }^{15}$ reported decadal variations in the $\mathrm{ET}_{0}$. Gao et al. ${ }^{16}$ reported a decreasing trend in $\mathrm{ET}_{0}$ at $46.7 \%$ of the weather station sites and an increasing trend in $\mathrm{ET}_{0}$ at $53.3 \%$ of the sites for the period of 1960 to 2012 in the arid and semiarid area of the West Liao River basin of China. They indicated that larger $\mathrm{ET}_{0}$ was recorded in the plains area, which gradually decreased towards the surrounding areas and was smaller for the mountain area. Yin et al. ${ }^{17}$ also reported a decreasing trend in $\mathrm{ET}_{0}$ in most regions 
across China during the period 1961-2008; however, an increasing trend in $\mathrm{ET}_{0}$ was observed in the cold temperate humid region and the tropical humid region in China. Inter-annual variation in precipitation has a dramatic impact on the vulnerable rainfed agriculture in the developing countries such a Madagascar with increasing effects of drought in the dry years and flooding in the wet years, exposing the population to famine and other socioeconomic disasters ${ }^{18,19}$ as well as challenges in water management in agricultural and natural resources settings. The seasonal and spatial distribution of the rainfall in Madagascar is affected by the county relief and associated landscape and topographical characteristics as the central massif along eastern Madagascar and Warm Western Indian Ocean sea surface temperature would result in enhanced moisture evaporation, latent heat transport and convection, leading to greater rainfall in the western Indian Ocean. ${ }^{19}$ About $70 \%$ of the Madagascar population is smallholder farmers whose livelihood fully depends on agriculture ${ }^{20,21}$ with almost no water management and conservation practices due to numerous reasons, including lack of information and data availability on crop water use. Recently, $\mathrm{USDA}^{22}$ revealed that rice production in 2017/2018 seasons in Madagascar is estimated at 3.5 million metric tons, representing $11 \%$ reduction as compared to the 5 -year average due to a severe drought in the central and northern regions of the country where nearly $80 \%$ of Madagascar's rice is grown. Moreover, seasonal rainfall during the first half of the rice growing season (November 2016 through February 2017) was the lowest in the past 36 years. The drought in the central and northern parts of the country reduced land area cultivated with rice and significantly affected crop yields. In addition, cropland was flooded in the north and northeast regions when Cyclone Enawo, the largest cyclone (Category 4) stroke Madagascar since 2004, which made landfall in early March 2017.22 These statistics and their implications to the population and agricultural and natural resources are alarming and there is a pressing need to investigate water management at regional or country level to aid in mitigating the effect of climate change on food production and project some adaptation strategies to climate change to assure decent harvest yields and increase resilience across Madagascar. Understanding the spatial and temporal variability of $\mathrm{ET}_{0}$ can aid in decision making regarding managing agricultural activities under irrigated and rainfed production systems. The present knowledge shows very limited data and information on the magnitude and location related $\mathrm{ET}_{0}$ across Madagascar. The objective of this study was to evaluate the spatial and temporal variation in monthly average and annual total grass-reference evapotranspiration $\left(\mathrm{ET}_{0}\right)$ across Madagascar for water resources planning, management, and projections for environmental and agricultural projects.

\section{Materials and methods}

\section{Study area and meteorological data used}

The study covers Madagascar, which is the largest African Island. Madagascar is roughly situated between 110 and 260 latitudes south and 420 and 500 longitudes east (Figure 1) and typically characterized as a low plateau and plains in the west, a plateau in central part, and coastal strip in the east. Madagascar is dominated by two seasons: hot and wet period from November to April and dry season from May to October. Climate datasets, including, daily average air temperature, relative humidity, solar radiation, and wind speed, that were collected at 22 weather stations across Madagascar for the period of 1980-2010 were used in the analyses. The long-term average climatic conditions are summarized in Table 1.

Table I Geographic coordinates and annual average climatic variables of the weather observatories in Madagascar

\begin{tabular}{|c|c|c|c|c|c|c|c|c|c|}
\hline Weather stations & $\begin{array}{l}\text { Latitude } \\
\text { DDNorth }\end{array}$ & $\begin{array}{l}\text { Longitude } \\
\text { DDEast }\end{array}$ & $\begin{array}{l}\text { Altitude } \\
\text { (m) }\end{array}$ & $\begin{array}{l}U_{2} \\
(\mathrm{~m} / \mathrm{s})\end{array}$ & $\begin{array}{l}\text { Tmax } \\
\left({ }^{\circ} \mathrm{C}\right)\end{array}$ & $\begin{array}{l}\text { Tmin } \\
\left({ }^{\circ} \mathrm{C}\right)\end{array}$ & $\begin{array}{l}\text { RHmax } \\
\text { (\%) }\end{array}$ & $\begin{array}{l}\text { RHmin } \\
\text { (\%) }\end{array}$ & $\begin{array}{l}\text { Rs } \\
\left(\mathrm{M} J / \mathrm{m}^{2}\right)\end{array}$ \\
\hline Ambohirsilaozana & -17.63 & 48.5 & 761 & 1.56 & 25.48 & 17.35 & 95.4 & 61.16 & 18.49 \\
\hline Andapa & -14.65 & 49.62 & 483.5 & 0.69 & 24.62 & 16.58 & 99.92 & 73.02 & 17.64 \\
\hline Ambohibary & -19.62 & 47.13 & 1657 & 1.82 & 22.49 & 12.93 & 97.13 & 56.54 & 20.11 \\
\hline Antsohihy & -14.88 & 47.98 & 33.82 & 2.55 & 32.39 & 21.42 & 79.16 & 44.9 & 21.8 \\
\hline Arrachart & -12.35 & 49.29 & 114 & 4.49 & 30.75 & 21.57 & 93.22 & 57.43 & 20.76 \\
\hline Amtsirabato & -15 & 50.32 & 87 & 3.07 & 28.56 & 22.23 & 99.03 & 72.16 & 17.83 \\
\hline Tolagnaro & -22.55 & 45.4 & 160 & 2.66 & 27.4 & 16.48 & 76.09 & 40.94 & 20.81 \\
\hline Toamasina & -18.11 & 49.39 & 7 & 0.76 & 28.2 & 21.01 & 88.62 & 59.38 & 16.58 \\
\hline Marovoay & -16.1 & 46.63 & 10 & 2.13 & 32.13 & 21.97 & 72.29 & 42.37 & 21.34 \\
\hline Maevatanana & -16.95 & 46.83 & 70 & 2.47 & 31.68 & 20.9 & 77.18 & 43.48 & 21.06 \\
\hline Maroantsetra & -15.43 & 49.73 & 5 & 0.53 & 26.93 & 19.27 & 99.43 & 71.29 & 17.5 \\
\hline Morombe & -21.75 & 43.38 & 5 & 2.5 & 31.76 & 20.65 & 69.07 & 36.92 & 22.61 \\
\hline Morndava & -20.29 & 44.32 & 8 & 1.76 & 32.11 & 19.64 & 89.64 & 46.63 & 22.07 \\
\hline Maintirano & -18.05 & 44.03 & 12 & 1.85 & 31.51 & 23.1 & 74.04 & 45.84 & 21.57 \\
\hline Mahanoro & -19.83 & 48.8 & 5 & $\mathrm{I} .47$ & 27.61 & 21.07 & 93.91 & 65.81 & 17.32 \\
\hline Mananjary & -21.2 & 48.36 & 0.27 & 1.4 & 27.27 & 20.82 & 93.61 & 64.86 & 17.12 \\
\hline
\end{tabular}


Table Continued....

\begin{tabular}{llllllllll}
\hline Weather stations & $\begin{array}{l}\text { Latitude } \\
\text { DDNorth }\end{array}$ & $\begin{array}{l}\text { Longitude } \\
\text { DDEast }\end{array}$ & $\begin{array}{l}\text { Altitude } \\
(\mathbf{m})\end{array}$ & $\begin{array}{l}\mathbf{U}_{2} \\
(\mathbf{m} / \mathbf{s})\end{array}$ & $\begin{array}{l}\text { Tmax } \\
\left({ }^{\circ} \mathbf{C}\right)\end{array}$ & $\begin{array}{l}\text { Tmin } \\
\left({ }^{\circ} \mathbf{C}\right)\end{array}$ & $\begin{array}{l}\text { RHmax } \\
(\%)\end{array}$ & $\begin{array}{l}\text { RHmin } \\
(\%)\end{array}$ & $\begin{array}{l}\text { Rs } \\
\left(\mathbf{M j} / \mathbf{m}^{2}\right)\end{array}$ \\
\hline Fianarantsoa & -21.44 & 47.11 & 1200 & 1.19 & 23.83 & 14.56 & 99.47 & 63.65 & 19.39 \\
Farafangana & -22.81 & 47.82 & 3 & 1.6 & 28.1 & 20.93 & 90.58 & 59.47 & 17.58 \\
Beroroha & -24.22 & 45.32 & 458 & 2.69 & 29.21 & 18.87 & 70.02 & 39.4 & 20.41 \\
Bekily & -21.67 & 45.17 & 180 & 2.16 & 32.19 & 19.75 & 73.55 & 38.03 & 21.15 \\
Besalampy & -16.74 & 44.48 & 30 & 1.71 & 31.86 & 22.76 & 73.7 & 45.25 & 21.4
\end{tabular}

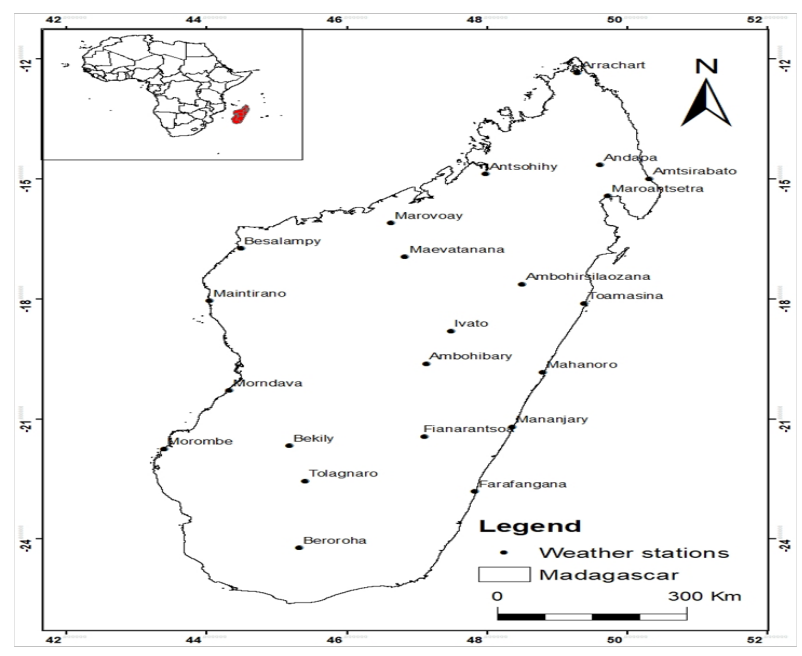

Figure I Map of Madagascar showing the weather stations under consideration in this study.

\section{Estimation of reference evapotranspiration}

Daily grass-reference ET (ET) was computed using the standardized ASCE form of the Penman-Monteith (ASCE-PM) equation. ${ }^{2}$ The Penman-Monteith reference evapotranspiration equation with fixed stomatal resistance values for grass surface is:

$$
E T_{o}=\frac{0.408 \Delta(R n-G)+\gamma C n u 2 /(T+273)(e s-e a)}{\Delta+\gamma(1+C d u 2)}
$$

where, $\mathrm{ET}_{0}$ is reference evapotranspiration ( $\mathrm{mm} /$ day), $\Delta$ is the slope of saturation vapor pressure versus air temperature curve $\left(\mathrm{kPaOC}^{-1}\right)$, $\mathrm{Rn}$ is net radiation at the crop surface $\left(\mathrm{MJ} \mathrm{m}^{-2} \mathrm{~d}^{-1}\right)$; $\mathrm{G}$ is soil heat flux density at the soil surface $\left(\mathrm{MJ} \mathrm{m}^{-2} \mathrm{~d}^{-1}\right)$; $\mathrm{T}$ is mean daily air temperature at $1.5-2.5 \mathrm{~m}$ height $\left({ }^{\circ} \mathrm{C}\right)$; $\mathrm{u} 2$ is mean daily wind speed at $2 \mathrm{~m}$ height $\left(\mathrm{ms}^{-1}\right)$; es is the saturation vapor pressure $(\mathrm{kPa})$; ea is the actual vapor pressure $(\mathrm{kPa})$; ea, the actual vapor pressure $(\mathrm{kPa})$; es-ea, saturation vapor pressure deficit $(\mathrm{kPa}) ; \gamma$ is psychrometric constant $(\mathrm{kPa} o \mathrm{C}-1)$; $\mathrm{Cn}$ is numerator constant that changes with reference surface and calculation time step $\left(900^{\circ} \mathrm{C} \mathrm{mm} \mathrm{s} 3 \mathrm{Mg}-1 \mathrm{~d}-1\right.$ for $24 \mathrm{~h}$ time steps for the grass-reference surface), $\mathrm{Cd}$ is denominator constant that changes with reference surface and calculation time step $\left(0.34 \mathrm{sm}^{-1}\right.$ for $24 \mathrm{~h}$ time steps). All parameters necessary for computing $\mathrm{ET}_{0}$ were computed according to the procedure developed in FAO-56 by Allen et al. ${ }^{1}$

\section{Spatial trend analysis}

The predicted values of monthly and annual total $\mathrm{ET}_{0}$ based on 30 years (from 1980 to 2010) of historical data were computed using the spline interpolation (Radial Basis Function) method which is an advanced, computationally intensive, geo-statistical estimation method. ${ }^{23}$ Spline interpolation is a deterministic interpolation method that fits a mathematical function through input data to create a smooth surface. The functions allow users to decide between smooth curves or tight straight edges between measured points. It can generate the accurate surfaces from only few sampled points. In each station, the estimation of the fitted surface, and the mean square error was calculated. The mean squared error calculations are repeated for a range of values of a smoothing parameter and the value that minimizes the mean squared error was used to determine the optimum smoothing. This process is called minimizing the generalized crossvalidation (GCV) or "leave one out" technique. In spline interpolation, surface is achieved through weights $(\gamma \mathrm{j})$ and number of points $(\mathrm{N})$. We used regularized spline with maximum of five and minimum of three neighboring stations. The weight parameter defines the weight of the third derivatives of the surface in the curvature minimization. A higher weight creates a smoother gridded surface. We used the interpolation procedures following Sharma et al. ${ }^{24}$

$$
S(x, y)=T(x, y)+\sum_{j=1}^{N} \lambda_{j} R\left(r_{j}\right)
$$

where, $\mathrm{T}$ is the constant trend, $\mathrm{r} \mathrm{j}$ is the distance from point $(\mathrm{x}, \mathrm{y})$ to the $\mathrm{jth}$ point, $\mathrm{R}$ is a weighted function of the distance between the interpolated point and jth data point $(\mathrm{j}=1,2,3 \ldots \mathrm{N}), \mathrm{N}$ is the number of known point and $\lambda \mathrm{j}$ is the unknown weight for the measured values at the jth location. For regularized spline interpolation, $\mathrm{T}$ and $r$ is defined as:

$$
\begin{gathered}
T(x, y)=a_{1}+a_{2} x+a_{3} y \\
R(r)=\frac{1}{2 \pi}\left\{\frac{r^{2}}{4}\left[\ln \left(\frac{2}{2 \pi}\right)+c-1\right]+\tau^{2}\left[K_{o}\left(\frac{r}{\tau}\right)+c+\ln \left(\frac{r}{2 \pi}\right)\right]\right\}
\end{gathered}
$$

where, $\tau$ is a weight parameter of the third derivatives of the surface in the curvature minimization expression, $r$ is the distance between the point and the sample, $\mathrm{K}_{\mathrm{o}}$ is a modified Bessel function, and $\mathrm{c}$ is a constant (0.577). Coefficient $\mathrm{a}_{1}, \mathrm{a}_{2} \& \mathrm{a}_{3}$ are found by the 
solution of a system of linear equations. The weight parameter was optimized, indicating the smoothness of the interpolant.

\section{Temporal trend analysis}

The Mann-Kendall test ${ }^{25,26}$ a non-parametric method for trend analysis, was used for the analysis of temporal trend in annual and monthly $\mathrm{ET}_{0}$. The Mann-Kendall test is a statistical test widely used for the analysis of trends in climatologic and hydrologic time series, ${ }^{27,28}$ which has two advantages:

I. It is a nonparametric test and does not require the data to be normally distributed and

II. The test has low sensitivity to abrupt breaks due to inhomogeneous time series. ${ }^{29}$

According to this test, the null hypothesis $\left(\mathrm{H}_{0}\right)$ is that there is no trend (the data is independent and randomly ordered) and the null hypothesis is tested against the alternative hypothesis $\left(\mathrm{H}_{1}\right)$, which assumes that there is a trend. The Mann-Kendall test statistic $\mathrm{S}$ is given as follows:

$$
\mathrm{S}=\sum_{\mathrm{j}=1}^{\mathrm{n}-1} \sum_{\mathrm{i}=\mathrm{j}+1}^{\mathrm{n}} \operatorname{sign}(\mathrm{xi}-\mathrm{xj})
$$

Where, $x i$ and $x j$ are the data values at time $i$ and $j, n$ is the length of the dataset and sign( ) is the sign function which can be computed as:

$$
\operatorname{sign}(x i-x j)=\left\{\begin{array}{c}
1 \text { if }(x i-x j)>0 \\
0 \text { if }(x i-x j)=0 \\
-1 \text { if }(x i-x j)<0
\end{array}\right.
$$

For $\mathrm{n}>10$, the test statistic $\mathrm{Z}$ approximately follows a standard normal distribution:

$$
\mathrm{Z}=\left\{\begin{array}{l}
\frac{\mathrm{S}-1}{\sqrt{\operatorname{Var}(\mathrm{s})}} \text { if } S>0 \\
0 \text { if } S=0 \\
\frac{\mathrm{S}+1}{\sqrt{\operatorname{Var}(\mathrm{S})}} \text { if } S<0
\end{array}\right.
$$

In which $\operatorname{Var}(\mathrm{S})$ is the variance of statistic $\mathrm{S}$.

A positive value of $Z$ indicates that there is an increasing trend and a negative value indicates a decreasing trend. The null hypothesis, Ho, that there is no trend in the records is either accepted or rejected depending on whether the computed $\mathrm{Z}$ statistics is less than or more than the critical value of $\mathrm{Z}$ statistics obtained from the normal distribution table at the $5 \%$ significance level. If $|Z|>Z(1-\alpha / 2)$ , the null hypothesis of no autocorrelation and trend in time series is rejected, in which $Z(1-\alpha / 2)$ is corresponding to the normal distribution with $\alpha$ being the significance level. If a time series has a trend, the magnitude of the trend can be denoted by the trend slope $\beta .^{30}$
$\hat{\mathrm{a}}=\operatorname{Median}\left(\frac{\mathrm{xi}-\mathrm{xj}}{\mathrm{i}-\mathrm{j}}\right) \quad \forall j<I$

Where, $x i$ and $x j$ are data values at the time ti and $t j(i>j)$, respectively.

Linear regression analysis was applied for analyzing trends in the time series. The main statistical parameter drawn from regression analysis is the slope which indicates the mean temporal change in the variable under study. A positive slope indicates an increasing trend, while a negative slope indicates a decreasing trend.

\section{Results and discussion}

\section{Spatial variation of the long-term average annual and monthly reference evapotranspiration}

Annual $\mathrm{ET}_{0}$ varied from $1081 \mathrm{~mm}$ to $2239 \mathrm{~mm}$ and averaged $1620 \mathrm{~mm} /$ year when all 22 weather stations were combined. ET showed spatial patterns across Madagascar (Figure 2). The highest value range of the long-term average annual ET $(1891-2111 \mathrm{~mm} /$ year) was obtained in the western coast between Morombe and Bekily and at the northwestern coast that cover an area from Marovoay to Arrachart (Figure 2). The rest of the low plateau and western plains, covering Beroroha, Tolagnaro, Morndava, Maintiranom Besalampy Maevatanana up to the northeast, had high annual average $\mathrm{ET}_{0}$, ranging from 1724 to $1890 \mathrm{~mm} /$ year. The western plateau and low plains were experiencing the highest annual evapotranspiration while the central plateau showing long-term average annual $\mathrm{ET}_{0}$ that ranged from 1362 to $1723 \mathrm{~mm} /$ year. The lowest and medium average annual $\mathrm{ET}_{0}$ were obtained in the eastern coastal strip, covering Farafangana, Fianarantsoa, Ambbohibary, Mahanoro, Toamasina, Ambohirsilaozana, Maoantsetra, Amtsirabato, and Andapa, which ranged from 1140 to $1361 \mathrm{~mm} /$ year (Figure 2). The high annual $\mathrm{ET}_{0}$ values at the western coast might be due to the dry climate along the western region with low relative humidity that results in increased evaporative demand of the local atmosphere. The extreme southern region had relatively high values of annual $\mathrm{ET}_{0}$ and that region correspond to the arid semi-desertic landscape. ${ }^{31}$ The eastern coastal region with the lowest annual $\mathrm{ET}_{0}$ is dominated by the equatorial climate with the highest precipitation. There were temporal and spatial variations in monthly average $\mathrm{ET}_{0}$ from January to December across Madagascar (Figure 3). The highest January average $\mathrm{ET}_{0}(>$ $5 \mathrm{~mm}$ /day) was observed in the southwest from Morombe to Bekily which is another region with hot and dry climatic characteristics in the Beroroha region while the lowest $\mathrm{ET}_{0}$, ranging from 3.27 to $3.7 \mathrm{~mm} /$ day, which was observed in the central eastern region to the extreme northeast region and along the extreme southern coast. The other part of the country showed medium monthly average ET during January. In February, the highest $\mathrm{ET}_{0}$ coverage expanded and the lowest $\mathrm{ET}_{0}$ area was reduced and was observed only in the extreme northeast, the central eastern region, covering an area from Ambohibary to Fianarantsoa and the surrounding region of Toamasina. Larger coverage of high $\mathrm{ET}_{0}(>5 \mathrm{~mm} /$ day) was observed in March. The south central regions and all of the western coastal region experienced the highest monthly average $\mathrm{ET}_{0}$ and the central plateau region showed medium average daily $\mathrm{ET}_{0}$ (Figure 3 ) and the lowest $\mathrm{ET}_{0}$ was observed along the east coast region from Fianarantsoa up the extreme 
northeast. In the central plateau, $\mathrm{ET}_{0}$ was within the range of 3.7-4.5 $\mathrm{mm} /$ day. Similar spatial variability in $\mathrm{ET}_{0}$ in March was observed in April; however, the southern and all of the eastern regions showed the lowest daily average $\mathrm{ET}_{0}$ range that continued expanding into May, June, and July. The medium $\mathrm{ET}_{0}$ range was diminishing with the expansion of both high and low $\mathrm{ET}_{0}$ areas. While $\mathrm{ET}_{0}$ increased from the west coastal region towards inland, $\mathrm{ET}_{0}$ had a decreasing trend towards the inland plateau. Reduced band in the central plateau showed daily average $\mathrm{ET}_{0}$ range of 3.71-4.5 mm/day. In August, daily ET higher than $5 \mathrm{~mm} /$ day was observed in the most part of the western and central regions of Madagascar and covered all of the western and central regions as well as the extreme southern regions in September. The minimum $\mathrm{ET}_{0}$ range was observed in the eastern coastal regions in and around Mananjary, Toamasina, Andana, Amtrirabato and Moroantsetra (Figure 3). The increase in daily average $\mathrm{ET}_{0}$ continued from the west towards east with more than $75 \%$ of the country having daily $\mathrm{ET}_{0}$ of higher than $5 \mathrm{~mm} /$ day. In December, the situation changed and there was a reduction in the daily average $\mathrm{ET}_{0}$ from the eastern coast towards the inland regions. The lowest $\mathrm{ET}_{0}$ range of $3.27-3.7 \mathrm{~mm} /$ day expanded to the regions between Fianaramtsoa and Ambohibary in the central eastern region and along the northeastern coastal region (Figure 3). Overall, the greatest coverage of the highest daily average $\mathrm{ET}_{0}$ was during September and October while the greatest coverage

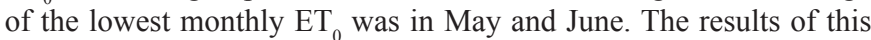
study are in agreement with those reported by Hobeichi et al. ${ }^{32}$ who indicated that the evapotranspiration had higher values in Sahel from September to November and in the high plateau of Madagascar from December to May.

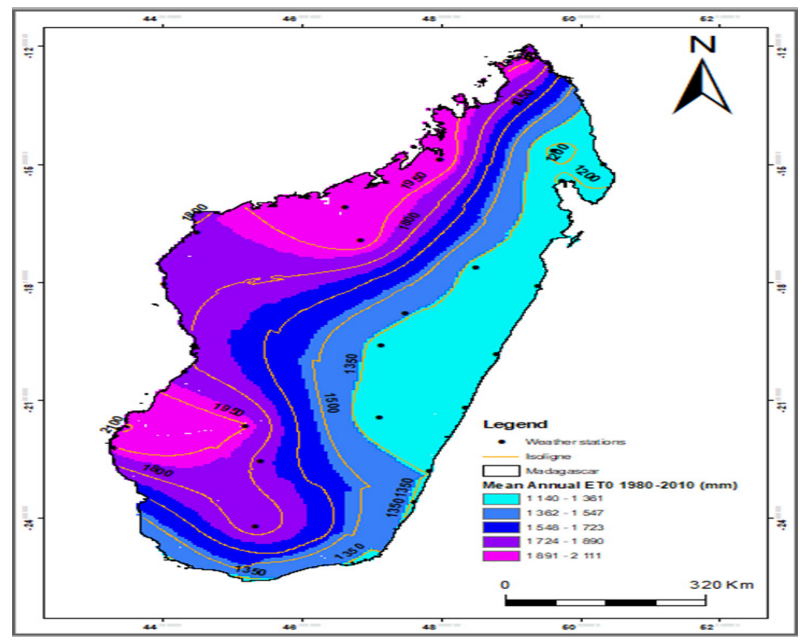

Figure 2 Spatial variation in long-term average annual ET0 across Madagascar.

\section{Temporal trends of annual and monthly reference evapotranspiration}

Except a non-significant decreasing trend in annual $\mathrm{ET}_{0}$ at Tolagnaro and Bekily, increasing trend in annual $\mathrm{ET}_{0}$ was observed at $91 \%$ of the weather station sites with increasing $\mathrm{ET}_{0}$ rates that varied from 0.07 to $3.15 \mathrm{~mm} /$ year. However, the variation in annual $\mathrm{ET}_{0}$ was significant only at 7 weather station sites (32\% of the stations) [Amhbohibary, Amtsirabato, Toamasina, Mahanoro, Mananjary, Ivato, and Fianarantsoa (Table 2)]. The linear regression between annual $\mathrm{ET}_{0}$ and year at these stations are presented in Figure 4. The greatest rate of change in annual $\mathrm{ET}_{0}$ was observed at Mahanoro at the eastern humid coastal region. Across the country, there was an increase in annual $\mathrm{ET}_{0}$ by a rate of $0.88 \mathrm{~mm} / \mathrm{year}$, which represents a total increase of $31 \mathrm{~mm}$ in $\mathrm{ET}_{0}$ from 1980 to 2010. Similarly, increasing trends in $\mathrm{ET}_{0}$ were reported for the Semiarid southern Senegal, ${ }^{6}$ in Burkina Faso, ${ }^{33}$ in Togo,${ }^{29}$ in Benin. ${ }^{34}$ The increasing trend in annual $\mathrm{ET}_{0}$ can imply a projected increase for demand water resources for food production across Madagascar. The results of this study are in agreement with those reported by Tabari et al. ${ }^{35}$ who observed overall increasing trend in annual $\mathrm{ET}_{0}$ at higher rate varying from 8.36 to $31.68 \mathrm{~mm} /$ year with statistically significant rates at $30 \%$ of the stations under their study in Iran. Liu et al. ${ }^{36}$ reported increase in annual $\mathrm{ET}_{0}$ in the upper and middle Yellow River Basin in China due to significant increase in air temperature and decrease in the relative humidity, which result in increasing evaporative demand. In contrast, decreasing trend in annual $\mathrm{ET}_{0}$ in reported in the arid land of Northwestern China by Zheng \& Wang. ${ }^{37}$ Wang et al. ${ }^{38}$ indicated significant decrease in annual $\mathrm{ET}_{0}$ at a rate of $0.68 \mathrm{~mm} / \mathrm{year}$ across China. Li et al. ${ }^{39}$ reported increase in annual $\mathrm{ET}_{0}$ at $75 \%$ of the weather station sites they studied while across the Pearl River Basin (China). Zhang et al. ${ }^{40}$ found a decreasing trend in $\mathrm{ET}_{0}$. While total annual $\mathrm{ET}_{0}$ might be very useful for annual and seasonal irrigation and water management planning, monthly $\mathrm{ET}_{0}$ might have more relevance in practical applications when agricultural crop production and irrigation practices are considered in terms of seasonal and in season water management for sustainable crop production across Madagascar where rainfed production is dominant and subject to in season drought spell and rainfall anomalies under climate change. Non-significant decreasing trend in monthly $\mathrm{ET}_{0}$ was observed at $68 \%$ of the weather station sites while February is dominated by nonsignificant increasing trend in monthly $\mathrm{ET}_{0}$, except in Maevatenana where monthly $\mathrm{ET}_{0}$ showed significant increasing trend (Table 3 ). Similar observations were made for March $\mathrm{ET}_{0}$ values, which showed an increasing trend at Ambohirsiloazanam Toamasina, Mahhanoro, and Ivato. Eight station sites showed significant increasing trend in April $\mathrm{ET}_{0}$ and non-significant trend was observed in May across all weather station sites. $\mathrm{ET}_{0}$ significantly increased only at Besalampy in June and only at Andapa in July. Monthly ET 0 showed more significant variability in August (36\% of stations), October (50\% of stations), and December (41\% of stations) (Table 3 ). At the weather station level, monthly $\mathrm{ET}_{0}$ showed significant variability at Mahanoro (March, April, August, October-December), Ivato (March-April, August and October-November) while other stations were slightly affected by variability in monthly $\mathrm{ET}_{0}$. At the country level, monthly $\mathrm{ET}_{0}$ showed decreasing trend in January, May, and December at the rates of $0.12,0.001 \& 0.099 \mathrm{~mm} / \mathrm{month}$, respectively. Increased trend in the monthly $\mathrm{ET}_{0}$ was observed in other months. Variability in available surface energy, relative humidity, and wind speed may greatly affect the variability of $\mathrm{ET}_{0}$ as the vapor pressure deficit constitutes the main driving force for evaporation demand between the crop system and the surrounding atmosphere. Mcvicar et al. ${ }^{41}$ reported that reference evapotranspiration was affected by land topography in the Loess Plateau, China. In Mongolia, ET 0 is influenced by the ocean, land cover, and topography. ${ }^{42}$ In the semiarid region of northeastern China, the peak daily evapotranspiration occurred in August for the degraded grassland and cropland land surface China ${ }^{43}$ The results of this study are in agreement with those reported by Davis ${ }^{44}$ who observed an increase in evapotranspiration across southern Africa, including Madagascar. 

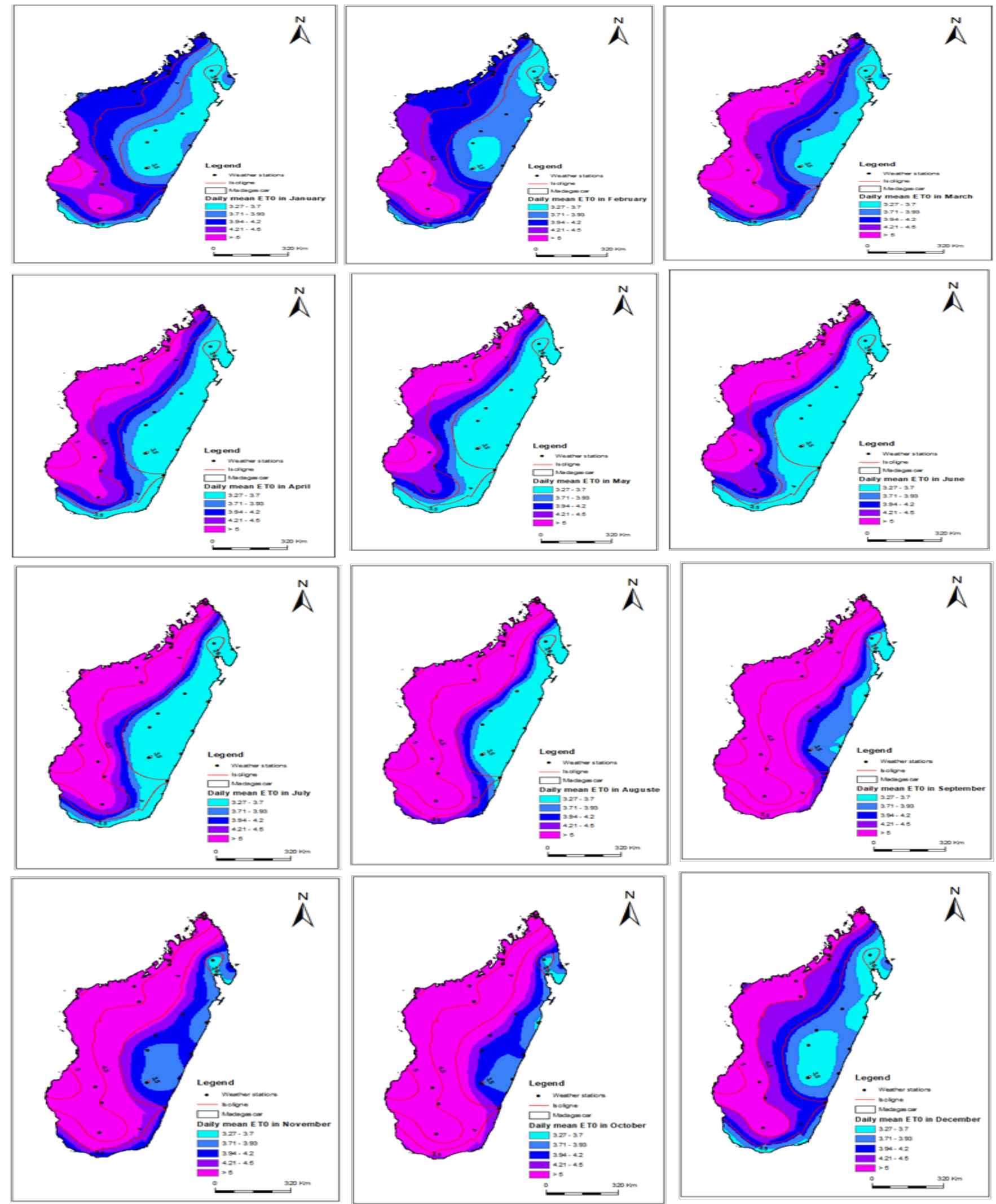

Figure 3 Spatial variation in long-term average monthly $\mathrm{ET}_{0}$ from January to December across Madagascar. 
Table 2 Summary of the Mann-Kendall trend test for annual ETO

\begin{tabular}{|c|c|c|c|c|c|c|}
\hline Locations & First year & Last year & Z-Stats & Significance & Sen's slope Q & B \\
\hline Ambohirsilaozana & 1980 & 2010 & 1.02 & n.s. & I.I5I & 1277.46 \\
\hline Andapa & 1980 & 2010 & 0.10 & n.s. & 0.090 & 1125.84 \\
\hline Ambohibary & 1980 & 2010 & 2.11 & $*$ & 1.453 & 1280.37 \\
\hline Antsohihy & 1980 & 2010 & 0.37 & n.s & 0.619 & 2060.53 \\
\hline Arrachart & 1980 & 2010 & 0.24 & n.s. & 0.482 & 1956.30 \\
\hline Amtsirabato & 1980 & 2010 & 1.73 & + & 1.136 & 1352.34 \\
\hline Tolagnaro & 1980 & 2010 & -0.31 & n.s. & -0.715 & 1770.63 \\
\hline Toamasina & 1980 & 2010 & 1.87 & + & 1.278 & I I 84.89 \\
\hline Marovoay & 1980 & 2010 & 0.20 & n.s. & 0.366 & 2012.54 \\
\hline Maevatanana & 1980 & 2010 & 0.27 & n.s. & 0.983 & 1997.69 \\
\hline Maroantsetra & 1980 & 2010 & 0.82 & n.s. & 0.557 & II 59.07 \\
\hline Morombe & 1980 & 2010 & 0.07 & n.s. & 0.070 & 2108.75 \\
\hline Morndava & 1980 & 2010 & 0.68 & n.s. & 0.982 & 1796.44 \\
\hline Maintirano & 1980 & 2010 & 0.31 & n.s. & 0.372 & 1833.74 \\
\hline Mahanoro & 1980 & 2010 & 2.82 & $* *$ & 3.149 & 1231.44 \\
\hline Mananjary & 1980 & 2010 & 3.09 & $* *$ & 2.381 & 1214.06 \\
\hline Ivato & 1980 & 2010 & 2.18 & $*$ & 1.621 & $|34| .5 \mid$ \\
\hline Fianarantsoa & 1980 & 2010 & 1.80 & + & $\mathrm{I} .775$ & 1199.40 \\
\hline Farafangana & 1980 & 2010 & 1.63 & n.s. & $\mathrm{I} .744$ & 1323.75 \\
\hline Bekily & 1980 & 2010 & -0.37 & n.s. & -0.919 & 1978.63 \\
\hline Beroroha & 1980 & 2010 & 0.37 & n.s. & 0.897 & 1860.11 \\
\hline Besalampy & 1980 & 2010 & 0,31 & n.s. & 0.239 & 1831.49 \\
\hline
\end{tabular}

N, Number of years; Z, Mann-Kendall test statistic; $f($ year $)=Q *($ year-firstData Year $)+B$

n.s, Non-significant, +, Significant at $5 \%$; *, Significant at I\%; **, Significant at $0.1 \%$; ***, Significant at $0.01 \%$

Table 3 Sen's slope estimates ( $\mathrm{mm} /$ day) and its significance for the temporal trend in monthly ET ${ }_{0}$ across Madagascar

\begin{tabular}{|c|c|c|c|c|c|c|c|c|c|c|c|c|}
\hline Locations & January & February & March & April & May & June & July & August & September & October & November & December \\
\hline Ambohirsilaozana & -0.003 & 0 & $0.008+$ & $0.011+$ & 0 & -0.002 & -0.006 & 0.006 & -0.001 & $0.013 *$ & 0.009 & 0.004 \\
\hline Andapa & 0.003 & -0.001 & 0.002 & 0.004 & 0.003 & -0.003 & $-0.005 *$ & -0.002 & -0.002 & 0.003 & 0.002 & 0.006 \\
\hline Ambohibary & -0.001 & 0.006 & 0.009 & $0.009 *$ & 0 & 0.002 & -0.002 & $0.008+$ & 0.005 & $0.02 * *$ & 0.008 & 0.004 \\
\hline Antsohihy & -0.01 & 0.009 & 0.007 & $0.014 *$ & -0.009 & 0.002 & 0.003 & -0.002 & 0.007 & 0.018 & 0.009 & -0.012 \\
\hline Arrachart & -0.009 & 0.001 & 0.004 & 0.012 & -0.007 & -0.005 & -0.003 & -0.001 & $0.009+$ & 0.009 & 0.007 & 0.013 \\
\hline Amtsirabato & 0.004 & 0.002 & 0.003 & $0.011+$ & 0.007 & 0.004 & -0.001 & 0.004 & -0.003 & 0.005 & 0.003 & $0.012+$ \\
\hline Tolagnaro & -0.01 & 0.007 & 0.003 & -0.013 & -0.005 & -0.01 & 0 & -0.005 & 0.002 & $0.016 *$ & 0.011 & -0.013 \\
\hline Toamasina & 0 & -0.002 & $0.01+$ & $0.011+$ & 0.004 & 0.001 & 0.002 & 0.004 & -0.001 & $0.007+$ & 0.005 & $0.008+$ \\
\hline Marovoay & -0.012 & 0.012 & 0.007 & 0.009 & -0.007 & 0.002 & 0.009 & 0 & 0.003 & 0.02 & 0.006 & $-0.025 * *$ \\
\hline Maevatanana & -0.008 & $0.014+$ & 0.01 & 0.008 & -0.002 & 0.007 & 0.006 & 0.002 & 0.002 & $0.025 *$ & 0.008 & $-0.02+$ \\
\hline Maroantsetra & 0.002 & -0.004 & -0.001 & 0.007 & 0.004 & -0.001 & -0.003 & 0.001 & -0.001 & 0.003 & 0.004 & 0.007 \\
\hline Morombe & -0.006 & 0.003 & -0.002 & -0.001 & -0.002 & 0.006 & 0.011 & $-0.011 *$ & -0.005 & 0.01 & -0.002 & -0.003 \\
\hline Morndava & -0.008 & 0.01 & 0.002 & 0.002 & -0.002 & 0.001 & 0.008 & $-0.01+$ & 0.011 & 0.008 & 0.015 & $-0.018 * *$ \\
\hline
\end{tabular}

Citation: Djaman K, Ndiaye PM, Koudahe K, Bodian A, et al. Spatial and temporal trend in monthly and annual reference evapotranspiration in Madagascar for the I980-20I0 period. Int J Hydro. 20I8:2(2); 95-I05. DOI: I0.15406/ijh.2018.02.00058 
Table Continued...

\begin{tabular}{|c|c|c|c|c|c|c|c|c|c|c|c|c|}
\hline Locations & January & February & March & April & May & June & July & August & September & October & November & December \\
\hline Maintirano & -0.005 & 0.007 & 0.007 & 0.003 & 0 & 0.002 & 0.002 & -0.001 & 0.004 & 0.006 & 0.005 & $-0.023 * * *$ \\
\hline Mahanoro & -0.001 & 0.005 & $0.018 *$ & $0.016 *$ & 0.005 & 0.004 & 0.004 & $0.009 *$ & 0.001 & $0.017 *$ & $0.015+$ & $0.015 *$ \\
\hline Mananjary & 0.001 & 0.008 & 0.011 & 0.011 & 0.002 & 0.001 & 0.001 & $0.009 *$ & 0.004 & $0.017 * *$ & 0.012 & 0.012 \\
\hline Ivato & -0.003 & 0.004 & $0.008+$ & $0.008 *$ & 0.002 & 0 & -0.001 & $0.008 * *$ & 0.003 & $0.021 * *$ & $0.01+$ & 0.004 \\
\hline Fianarantsoa & 0.001 & 0.006 & 0.005 & $0.007+$ & 0.002 & 0.002 & -0.003 & $0.01 *$ & 0.007 & $0.021 * * *$ & 0.009 & 0.001 \\
\hline Farafangana & -0.004 & 0.007 & 0.009 & 0.004 & 0 & 0 & 0.002 & $0.01 *$ & 0.003 & $0.017 *$ & 0.01 & 0.009 \\
\hline Bekily & -0.008 & 0.01 & 0.011 & -0.012 & -0.001 & -0.001 & 0.009 & -0.01 & 0.001 & 0.009 & 0.006 & $-0.015+$ \\
\hline Beroroha & 0.002 & 0.007 & 0.006 & -0.003 & -0.004 & 0 & 0.005 & 0.003 & 0.008 & $0.018 *$ & $0.016 *$ & -0.005 \\
\hline Besalampy & -0.008 & 0.014 & 0.008 & 0.008 & 0.009 & $\begin{array}{l}0.015 \\
* *\end{array}$ & 0.003 & -0.007 & 0.001 & -0.002 & 0.001 & $-0.031 * * *$ \\
\hline
\end{tabular}
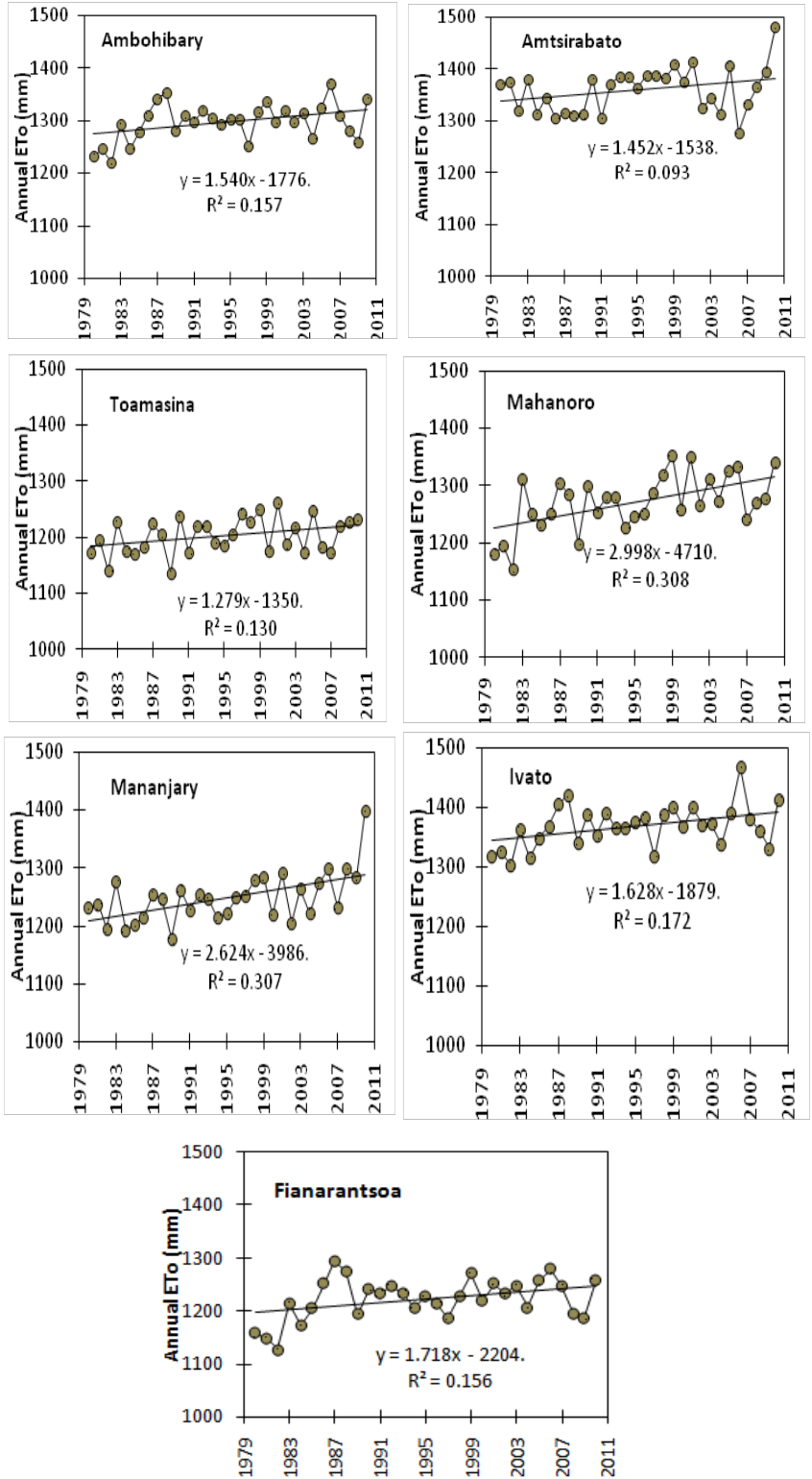

Figure 4 Variation in annual total reference evapotranspiration (ET, ) at the weather station sites with significant temporal trend during the 19802010 period.

\section{Potential effects of the variability of $\mathrm{ET}_{0}$ on crop production across madagascar}

The $\mathrm{ET}_{0}$ patterns observed might be influenced by the topography and trade wind circulations as it significantly impacted rainfall and temperature patterns in the country. ${ }^{45-46}$ The eastern coastal region has a humid climate covered by rainforests. The middle plateau is subhumid while the central and north west has a dry climate and the south and the southwest region has spiny desert and are in a Please word replace with sub-arid zone, dry forest and some mangroves occur in the west and northwest. ${ }^{47}$ Annual precipitation, mean annual temperature, precipitation seasonality, actual and reference evapotranspiration, topographic range, geological heterogeneity, vegetation-type heterogeneity, the human influence index, and average historical human population density were positively correlated to the climate. ${ }^{48}$ Recent study revealed a decrease in precipitation in the eastern coastal area of Madagascar from $15^{\circ} \mathrm{S}$ to $25^{\circ} \mathrm{S}$ after early $1990 \mathrm{~s}$, with the southern area experiencing a particularly large reduction in rainfall bands. ${ }^{49}$ Large variability of climate across Madagascar is due to its geographical position in the Indian Ocean, the large range of altitudes that create microclimates. The peak $\mathrm{ET}_{0}$ does not coincide with rainy season (November-April) while rainfall occurs at the southern and eastern coasts during the winter (May - October) ${ }^{46}$ This can have a large impact on seasonal rainfall across Madagascar and while the northeastern region receives $3500 \mathrm{~mm}$ of annual rainfall, the western region receives very low rainfall, ${ }^{46}$ creating large discrepancies in rainfall among regions and impact land cover and food production. However the projections by Hewitson \& Crane $^{50}$ as well as Tadross et $a l .{ }^{46}$ projected an increase in summer (January-April) rainfall, and a decrease in winter (July-September) along the southeast coast by 2050 and projected wetter seasons elsewhere. The increase in $\mathrm{ET}_{0}$ vs. reduced rainfall in the western regions of Madagascar might create severe aridity and drought condition, which can be prejudicial to food production and livestock. ${ }^{6,28}$ Under rainfed as well as irrigated crop production, the annual and monthly $\mathrm{ET}_{0}$ might help deciding on the crop choice, decision on planting period and crop management practices to meet crop water demand via utilizing precipitation when the producers are aware of the season or annual precipitation forecast. Conservation agriculture, mulching practices and, minimum tillage practices should also help on managing the available soil water in relation to crop evapotranspiration. The combined effect of increase in $\mathrm{ET}_{0}$ and decrease in precipitation can create significant challenges for food production via increasing aridity index. ${ }^{6,28}$ Droughttolerant varieties can be adopted to mitigate the impact of drought and maintain acceptable level of crop production. Some adaptation measures and strategies for increasing resilience and coping with 
risks as changing usual crops to less water demanding one or short season crops are of great importance. ${ }^{28,51,52}$ Also drip irrigation can provide additional benefits over sprinkler and surface irrigation systems since it considerably or significantly reduces surface water evaporation. ${ }^{53}$ Even though the management of drip irrigation could be slightly more complicated than sprinkler irrigation, efforts need to be made by agriculture agencies to train farmers on this technology, which can aid in mitigating aforementioned potential challenges. The adaptation strategies to the increase in $\mathrm{ET}_{0}$ can range from allocating more water demanding crop to less water demanding ones (new crops, new varieties), adopting agriculture conservation practices such as minimum tillage, cover crop incorporation into well documented cropping systems, efficient irrigation water and rainfall water management to cope with high water productivity. ${ }^{28,52}$ Rainwater harvesting is another approach to mitigate the drought during the drought spell periods of the cropping season. ${ }^{52,54-56}$ Moreover, harvested water could serve in environmental, industrial and domestic use. $^{54,57}$ Rain water harvested and used in agriculture increased crop productivity ${ }^{58}$ by $30-50 \%$ in South Africa, ${ }^{59}$ in Kenya, ${ }^{60-61}$ and in Malawi. ${ }^{62}$ This technic had improved water management under semiarid climate and rainfed and irrigated agriculture elsewhere. ${ }^{63-65}$

\section{Summary and Conclusion}

Spatial and temporal variability in monthly average and annual total reference evapotranspiration $\left(\mathrm{ET}_{0}\right)$ estimated using PenmanMonteith method from daily climatic variables across Madagascar was analyzed for the period of 1980-2010. The required climatic variables such as minimum and maximum air temperature, minimum and maximum relative humidity, solar radiation and wind speed were collected from 22 weather stations for the study period. The Mann-Kendall test and the Sen's method were used for temporal trend analysis in monthly average and annual total $\mathrm{ET}_{0}$ while the spline interpolation method was used to map the spatial variation in annual and monthly average $\mathrm{ET}_{0}$ across Madagascar. The results showed three main patterns in spatial distribution of $\mathrm{ET}_{0}$ with south to north direction: the western semiarid regions with the highest ET value, the humid eastern regions with the lowest $\mathrm{ET}_{0}$ and the central plateau with the medium $\mathrm{ET}_{0}$ values. The spatial distribution of $\mathrm{ET}_{0}$ seemed to be impacted by the landscape and topography. The highest daily $\mathrm{ET}_{0}$ occurs during September and October with the high evapotranspiration progressing from the west coastal regions towards the plateau. There was a wide variation in the annual total $\mathrm{ET}_{0}$ over the three topographic landscapes. Annual total $\mathrm{ET}_{0}$ varied from 1081 at Andapa in the northeast region to $2239 \mathrm{~mm}$ at Antsohihy in the northwestern coastal region. There was a significant increasing trend in annual total $\mathrm{ET}_{0}$ at $32 \%$ of the weather station sites and there was a wide variation in the monthly average daily $\mathrm{ET}_{0}$ among the weather station sites. The results of this study could serve as a guideline and could be used by agricultural and environmental project managers, hydrologists, agronomists, irrigation professionals, students, and university researchers to improve water management for better water productivity under the Madagascar agricultural, environmental conditions. The upward trend in $\mathrm{ET}_{0}$ should be considered with regards to some water conservations practices, cropping system, crop and varietal choice, planting time and plant density for resilience and better water management for enhancing the sustainability of irrigated and rainfed agriculture in Madagascar.

\section{Acknowledgment}

None.

\section{Conflict of interest}

None.

\section{References}

1. Allen RG, Pereira LS, Raes D, et al. Crop evapotranspiration guidelines for computing crop water requirements. Italy: Food and Agriculture Organization; 1988. p. 1-15.

2. ASCE-EWRI. The ASCE standardized reference evapotranspiration equation. In: Allen RG, Walter IA, Elliot RL, et al. editors. Environmental and Water Resources Institute (EWRI) of the American Society of Civil. Engineers, ASCE, Standardization of Reference Evapotranspiration Task Committee Final Report, VA: American Society of Civil Engineers (ASCE); 2005:1-70.

3. Tabari H, Marofi S, Aeini A, et al. Trend analysis of reference evapotranspiration in the western half of Iran. Agricultural and Forest Meteorology. 2011;151(2):128-136.

4. Gocic M, Trajkovic S. Analysis of trends in reference evapotranspiration data in a humid climate. Hydrological Sciences Journal. 2014;59(1):165-180.

5. Palumbo DA, Domenico V, Pasquale C, et al. Time trend in reference evapotranspiration: analysis of a long series of agrometeorological measurements in Southern Italy. Irrigation and Drainage Systems. 2012;25(4):395-411.

6. Koudahe K, Djaman K, Bodian A, et al. Trend Analysis in Rainfall, Reference Evapotranspiration, and Aridity Index in the Southern Senegal: Adaptation to the Vulnerability of Rainfed Rice Cultivation to Climate Change. Atmospheric and Climate Sciences. 2017;7(4):476-495.

7. Feng Y, Cui N, Zhao L, et al. Spatiotemporal variation of reference evapotranspiration during 1954-2013 in Southwest China. Quaternary International. 2017;441:129-139.

8. Song ZW, Zhang HL, Snyder RL, et al. Distribution and Trends in Reference Evapotranspiration in the North China Plain. Journal of Irrigation and Drainage Engineering. 2010;136(4):240-247.

9. Jhajharia D, Dinpashoh Y, Kahya E, et al. Trends in reference evapotranspiration in the humid region of northeast India. Hydrological Processes. 2012;26:421-435.

10. Irmak S, Kabenge I, Skaggs K, et al. Trend and magnitude of changes in climate variables and reference evapotranspiration over 116-year period in the Platte River Basin, central Nebraska-USA. Journal of Hydrology. 2012;420-421:228-244.

11. Huo ZL, Dai XQ, Feng SY, et al. Effect of climate change on reference evapotranspiration and aridity index in arid region of China. Journal of Hydrology. 2013;492(7):24-34.

12. Zhang K, Pan S, Zhang W, et al. Influence of climate change on reference evapotranspiration and aridity index and their temporal-spatial variations in the Yellow River Basin, China, from 1961 to 2012. Quaternary International. 2015;380-381(4):75-82.

13. Xu CY, Gong LB, Jiang T, et al. Analysis of spatial distribution and temporal trend of reference evapotranspiration in Changjiang catchments. Journal of Hydrology. 2006;327(1-2):81-93.

14. Liu X, Zhang D. Trend analysis of reference evapotranspiration in northwest China: The roles of changing wind speed and surface air 
temperature. Hydrological Processes. 2013;27(26):3941-3948.

15. Xing W, Wang W, Shao Q, et al. Periodic fluctuation of reference evapotranspiration during the past five decades: Does Evaporation Paradox really exist in China? Scientific Reports. 2016:39503.

16. Gao Z, He J, Dong K, et al. Trends in reference evapotranspiration and their causative factors in the West Liao River Basin, China. Agric For Meteorol. 2017;232:106-117.

17. Yin $\mathrm{YH}, \mathrm{Wu} \mathrm{S}$, Chen $\mathrm{G}$, et al. Attribution analyses of potential evapotranspiration changes in China since the 1960s. Theoretical and Applied Climatology. 2010;101(1-2):19-28.

18. GFDRR (2014) Global facility for disaster reduction and recovery.NW Washington DC, 20433, USA: Inroads to Resilience; 2013.

19. Scroxton N, Burns SJ, McGee D, et al. Hemispherically in-phase precipitation variability over the last 1700 years in a Madagascar speleothem record. Quaternary Science Reviews. 2017;164(15):25-36.

20. Zeller M, Lapenu C, Minten B, et al. Pathways of rural development in Madagascar: an empirical investigation of the critical triangle between environmental sustainability, economic growth and poverty alleviation. $Q$ J Int Agric. 1999;2:1-57.

21. Minten B, Barrett C. Agricultural Technology, Productivity, and Poverty in Madagascar. World Development. 2008;36(5):797-822.

22. USDA. Madagascar Rice: Severe Drought Lowers Production. USA: USDA; 2017.

23. Franke R. Smooth interpolation of scattered data by local thin plate splines. Computers and Mathematics with Applications. 1982;8(4):273-281.

24. Sharma V, Irmak S, Djaman K, et al. Large-Scale Spatial and Temporal Variability in Evapotranspiration, Crop Water-Use Efficiency, and Evapotranspiration Water-Use Efficiency of Irrigated and Rainfed Maize and Soybean. Journal of Irrigation and Drainage Engineering. 2015;142(3):04015063.54.

25. Mann HB. Non-parametric test against trend. Econometrica. 1945;13(3):245-259.

26. Kendall MG. Rank Correlation Methods. 4th ed. Charles Griffin: London 1975 .

27. Mavromatis T, Stathis D. Response of the Water Balance in Greece to Temperature and Precipitation Trends. Theoretical and Applied Climatology. 2011;104(1-2):13-24.

28. Djaman K, Balde AB, Rudnick DR, et al. Long-term trend analysis in climate variables and agricultural adaptation strategies to climate change in the Senegal River Basin. International Journal of Climatology. 2016;37(6):2873-2888.

29. Djaman K, Ganyo K. Trend analysis in reference evapotranspiration and aridity index in the context of climate change in Togo. Journal of Water and Climate Change. 2015;6(4):848-864.

30. Sen PK. Estimates of the regression coefficient based on Kendall's Tau. Journal of the American Statistical Association 1968;63:1379-1389.

31. Randriamahefasoa TSM, Reason CJC. Interannual variability of rainfall characteristics over southwestern Madagascar. Theoretical and Applied Climatology. 2017;128(1-2):421-437.

32. Hobeichi S, Abramowitz G, Evans J, et al. Derived Optimal Linear Combination Evapotranspiration (DOLCE): a global gridded synthesis ET estimate. Hydrology and Earth System Sciences Discussions. 2017;22:1317-1336.
33. Ibrahim B. Characterization of the Rainy Seasons in Burkina Faso in a Climate Change Context on the Nakambé Basin. USA: Institut International d'Ingénierie de l'Eau et de l'Environnement (2iE), l'Université Pierre et Marie Curie; 2012.

34. Obada E, Alamou EA, Chabi A, et al. Trends and Changes in Recent and Future Penman-Monteith Potential Evapotranspiration in Benin (West Africa). Hydrology. 2017;4(3):38.

35. Tabari H, Aeini A, Talaee PH, et al. Spatial distribution and temporal variation of reference evapotranspiration in arid and semi-arid regions of Iran. Hydrological Processes. 2012;26(4):500-512.

36. Liu Q, Yang Z, Cui B, et al. The temporal trends of reference evapotranspiration and its sensitivity to key meteorological variables in the Yellow River Basin, China. Hydrological. 2010;24(15):171-2181.

37. Zheng C, Wang Q. Spatiotemporal variations of reference evapotranspiration in recent five decades in the arid land of Northwestern China. Hydrological Processes. 2014;28(25):6124-6134.

38. Wang Z, Xie P, Lai C, et al. Spatiotemporal variability of reference evapotranspiration and contributing climatic factors in China during 1961-2013. Journal of Hydrology. 2017;544:97-108.

39. Li Z, Zheng FL, Liu WZ. Spatiotemporal characteristics of reference evapotranspiration during 1961-2009 and its projected changes during 2011-2099 on the Loess Plateau of China. Agric. Forest Meteorology. 2012;154-155:147-155.

40. Zhang Q, Xu CY, Chen XH. Reference evapotranspiration changes in China: natural processes or human influences. Theoretical and Applied Climatology. 2011;103(2-4):479-488.

41. McVicar TR, Van NTG, Li L, et al. Spatially distributing monthly reference evapotranspiration and pan evaporation considering topographic influences. Journal of Hydrology. 2007;338:196-220.

42. Yu W, Wu T, Wang W, et al. Spatiotemporal Changes of Reference Evapotranspiration in Mongolia during 1980-2006. Advances in Meteorology Article. 2016;ID 9586896:14.

43. Liu H, Feng J. Seasonal and interannual variations of evapotranspiration and energy exchange over different land surfaces in a semiarid area of China. Journal of Applied Meteorology and Climatology. 2012;51:1875-1888.

44. Davis C. Climate Risk and Vulnerability: a handbook for southern Africa. Pretoria, South Africa: Council for Scientific and Industrial Research;2011.

45. Jury MR, Parker BA, Raholijao N, et al. Variability of summer rainfall over Madagascar: Climatic determinants at interannual scales. International Journal of Climatology. 1995;15(12):1323-1332.

46. Tadross M, Randriamarolaza L, Rabefitia Z, et al. Climate change in Madagascar; recent past and future. Washington DC: World Bank;2008.

47. Dausmann KH, Warnecke L. Primate Torpor Expression: Ghost of the Climatic Past. Physiology (Bethesda). 2016;31(6):398-408.

48. Rakotoarinivo M, Blach OA, Baker WJ, et al. Palaeo-precipitation is a major determinant of palm species richness patterns across Madagascar: a tropical biodiversity hotspot. Proc Bio Sci 2013;280:20123048.

49. Morishima W, Akasaka I. Seasonal trends of rainfall and surface temperature over southern Africa. African Study Monograph Suppl. 2010;40:67-76.

50. Hewitson BC, Crane RG. Consensus between GCM climate change projections with empirical downscaling: precipitation downscaling over South Africa. International Journal of Climatology. 2006;26:1315-1337. 
51. Chuku CA, Okoye C. Increasing resilience and reducing vulnerability in subSaharan African agriculture: Strategies for risk coping and management. African Journal of Agricultural Research. 2009;4:1524-1535.

52. Harvey CA, Rakotobe ZL, Rao NS, et al. Extreme vulnerability of smallholder farmers to agricultural risks and climate change in Madagascar. Philosophical Transactions of the Royal Society B: Biological Sciences. 2014;369,20130089.

53. Irmak S, Djaman K, Rudnick DR. Effect of full and limited irrigation rate and frequency on subsurface drip-irrigated maize evapotranspiration, yield, water use efficiency and yield response factors. Irrigation Science. 2016;34(4):271-286.

54. Hatibu N, Mahoo H. Rainwater harvesting technologies for agricultural production: A case for Dodoma, Tanzania. In: Kaumbutho PG, Simalenga TE editorss. Harare, Zimbabwe: Conservation tillage with animal traction. A resource book of the Animal Traction Network for Eastern and Southern Africa (ATNESA); 1999. p. 173.

55. Pachpute JS, Tumbo SD, Sally H, et al. Sustainability of rainwater harvesting systems in rural catchment of sub-Saharan Africa. Water Resources Management. 2009;23(13):2815-2839.

56. Rockström J, Falkenmark M. Increase water harvesting in Africa. Nature. 2015;519:283-285

57. Sutherland DC, Fenn CR. Assessment of water supply options. Cape Town: Prepared for the World Commission on dams; 2000.

58. Siegert K. Introduction to water harvesting: some basic principles for planning, design and monitoring. In: Water Harvesting for Improved Agricultural Production, Proceedings of the FAO Expert Consultation, Cairo, Egypt, November 1993, Rome. Italy. Cape Town: FAO; 1993.

59. Botha JJ, Van RLD, Anderson JJ, et al. Application of in-field rainwater harvesting in rural villages in semiaridareas of South Africa. Bloemfontein South Africa: Proceedings of the symposium and workshop on water conservation technologies for sustainable dryland agriculture in subSaharan Africa; 2003. p. 25-32.

60. Gicheru PT, Gachene CKK, Mbuvi JP, et al. Effects of soil management practices and tillage systems on soil water conservation and maize yield on a sandy loam in semi-arid Kenya. Bloemfontein South Africa: Proceedings of the symposium and workshop on water conservation technologies for sustainable dryland agriculture in sub-Saharan Africa; 2003. p. 18-24

61. Biamah EK, Nhlabathi NN. Conservation tillage practices for dryland crop production in semi-arid Kenya: promotion of conservation tillage techniques for improving household food security in Iiuni, Machakos, Kenya. Bloemfontein South Africa: Proceedings of the symposium and workshop on water conservation technologies for sustainable dryland agriculture in sub-Saharan Africa; 2003. p. 45-50.

62. Chilimba ADC, Kabambe VH. The effect of maize stover mulching and ridging techniques on soil water conserved and grain yield in Malawi. Bloemfontein South Africa: Proceedings of the symposium and workshop on water conservation technologies for sustainable dryland agriculture in sub-Saharan Africa; 2003. p. 51-55.

63. Lasage R, Verburg PH. Evaluation of small scale water harvesting techniques for semi-arid environments. Journal of Arid Environments. 2015;118:48-57.

64. Adham A, Riksen M, Ouessar M, et al. A Methodology to Assess and Evaluate Rainwater Harvesting Techniques in (Semi-) Arid Regions. Water. 2016;8(5):198.

65. Bansal V, Tumwesige V, Smith JU. Water for small-scale biogas digesters in sub-Saharan Africa. GCB Bioenergy. 2017;9(2):339-357. 